\title{
PENERAPAN TEKNOLOGI SEBAGAI INOVASI PENDIDIKAN
}

\author{
Dellaneira Btari Anantiwi \\ Email: 1810111420016@mhs.ulm.ac.id \\ Program Studi Pendidikan Sejarah Fakultas Keguruan dan Ilmu Pendidikan \\ Universitas Lambung Mangkurat \\ Banjarmasin
}

\begin{abstract}
Abstrak
Perkembangan dunia ilmu pengetahuan dan teknologi semakin hari semakin tidak terbayangkan oleh kemampuan akal manusia biasa, oleh karena itu diperlukan suatu pengetahuan, keterampilan dan sikap yang dapat mengikuti perkembangan dan kemajuan ilmu pengetahuan dan teknologi sekarang ini sebagai cara untuk mengimbangi perkembangan dan kemajuan ilmu pengetahuan dan teknologi tersebut. Lembaga pendidikan formal, nonformal dan informal sebagai wahana penghasil sumber daya manusia dengan semua unsur penyelenggaraannya merupakan salah satu kunci dalam menghadapi era teknologi dan informasi. Selanjutnya tenaga pendidik wajib menguasai ilmu pengetahuan dan teknologi dalam mentrasnfer materi pelajaran kepada para peserta didik, sehingga para peserta didik belajar dalam proses pembelajaran akan lebih bermakna atau dengan kata lain paradigma mengajar akan lebih cenderung kepada "student center" bukan sebaliknya cenderung kepada "teacher center", karena jaman yang mempengaruhi keadaan. Teknologi informasi telah menjadi fasihan pengalihan buku, guru dan sistem pengajaran yang sebelumnya konvensional. Penyebab Teknologi Informasi ilmu pengetahuan dalam tumbuh dan berkembang. Namun, TIK juga memiliki dampak positif dan negatif terhadap kehidupan, salah satu yang menonjol adalah di bidang pendidikan
\end{abstract}




\section{PENDAHULUAN}

Peran TIK (Teknologi Informasi dan Komunikasi) semakin nyata dalam berbagai bidang, bahkan dalam peningkatan keilmuan, penggunaan TIK diharapkan mampu mendorong kebangkitan Indonesia dalam era globalisasi. Untuk itu, pemerintah melalui Inpres no. 6/2001 telah berupaya untuk menetapkan kebijakan nasional dalam hal TIK dengan visi untuk membangun suatu pengetahuan yang berdasarkan masyarakat Telematika Nusantara. Karena sangat minimnya penggunaan/penerapan TIK di negara kita, menyebabkan semakin tertinggalnya negara kita dari negara lain. Menguasai TIK secara mendasar dapat mengurangi ketergantungan pada bangsa-bangsa lain.

Sebagai bahan pertimbangan, kita bisa melihat negara-negara tetangga kita seperti: Singapore, Malaysia atau India. Khususnya India, apakah mereka memiliki perekonomian yang lebih baik dari Indonesia? Kenapa mereka memiliki pakar-pakar IT yang sangat diperhitungan di dunia? Apakah SDM kita tidak bagus? Apakah guru-guru/tenaga pengajar yang melahirkan SDM tidak berkualitas? Untuk menjawab pertanyaan-pertanyaan di atas, baik secara pribadi maupun bersama-sama dengan pemerintah harus bisa intropeksi diri. Mulai dari diri sendiri, seorang guru harus berusaha mulai mengenalkan TI (Teknologi Informasi) terhadap anak didiknya, atau menggunakan TIK tesebut dalam proses belajar mengajar. Proses inilah yang disebut sebagai Pembelajaran Berbasis Komputer. Dengan dikeluarkannya kurikulum 2004, yang mengikutkan mata pelajaran TIK dalam pendidikan SMP, SMU dan SMK, adalah merupakan langkah yang sangat tepat untuk menghadapi era globalisasi ini. Lahirnya kurikulum TI 2004 ini, memunculkan masalah baru, bagaimana kita menerapkan/ mengimplementasikan Kurikulum TI 2004 ini, sehingga dapat mencapai sasaran dan tujuan yang diharapkan oleh pemerintah. Realita di lapangan, ada beberapa hambatan dalam penerapan kurikulum TIK ini. Baik itu, karena minimnya sarana (komputer) dan juga pengajar yang kompeten untuk memegang mata pelajaran tersebut.

Dengan berkembangnya dan bertambah majunya jaman, maka system Pendidikan juga harus menhgikuti perkembangan jaman agar tetap bisa sejajar dengan majunya peradaban. Peranan media pembelajaran tidak dapat dipisahkan dengan proses pembelajaran. Menurut AECT (Association of Education and Communication Technology) yang dikutip oleh 
Basyaruddin (2002) "media adalah segala bentuk yang dipergunakan untuk proses penyaluran informasi”. Sedangkan menurut Steffi Adam dan Muhammad Taufik Syastra (2015) bahwa media pembelajaran adalah segala sesuatu baik berupa fisik maupun teknis dalam proses pembelajaran yang dapat membantu guru untuk mempermudah dalam menyampaikan materi pelajaran kepada siswa sehingga memudahkan pencapaian tujuan pembelajaran yang telah dirumuskan. Selanjutnya (Joni Purwono, dkk, 2014) menjelaskan bahwa media pembelajaran memiliki peranan penting dalam menunjang kualitas proses belajar mengajar. Media juga dapat membuat pembelajaran lebih menarik dan menyenangkan. Salah satu media pembelajaran yang sedang berkembang saat ini adalah media audio visual.

\section{PERAN GURU SEBAGAI SEBUAH PROFESI}

Guru merupakan seseorang yang sangat berperan penting dalam dunia pendidikan. Pendidikan merupakan sebuah sistem sosial yang dilakukan dalam rangka menjadikan manusia sebagai manusia seutuhnya. Manusia yang memiliki pengetahuan dalam membentuk daya nalar sehingga mampu memberikan pertimbangan berdasarkan akal pikirannya yang jernih. Manusia yang memiliki keterampilan sehingga mampu mengaktualisasikan dirinya bagi kemasalahatan diri dan lingkungannya. Sebab, pendidikan berusaha untuk mentransformasikan keadaan suatu masyarakat menuju keadaan yang lebih baik.

Guru adalah profesi yang mulia. Oleh karena itu, banyak mahasiswa yang berminat kuliah di Fakultas Keguruan dan Ilmu Pendidikan. Dengan harapan setelah lulus nanti bisa menjadi guru muda yang kreatif dan inovatif untuk memberikan ilmu yang seluas-luasnya kepada para peserta didik. Namun, tidaklah mudah untuk menjadi guru yang sesungguhnya. Kebanyakan guru hanya menjalankan tugasnya dalam proses pembelajaran, yaitu menyampaikan materi kepada siswa, memberikan tugas, dan melakukan penilaian. Jarang guru yang kratif dan inovatif dalam melakukan Kegiatan Belajar Mengajar (KBM). Padahal 
hal ini sangat penting untuk menumbuhkan semangat dan motivasi untuk siswa. Apalagi di masa pandemi Covid-19 ini, beberapa siswa yang ditanyakan merasa bosan dengan model pembelajaran yang itu-itu saja. Guru mereka kurang kreatif dan inovatif untuk merancang proses pembelajaran seperti yang diharapkan para siswa.

Cara yang paling sederhana untuk memahami perubahan masyarakat sosial dan kebudayaan adalah dengan membuat rekapitulasi dari semua perubahan yang terjadi di dalam masyarakat. Bahkan, jika ingin mendapatkan gambaran yang lebih jelas lagi mengenai perubahan masyarakat dan kebudayaan, semua kejadian yang sedang berlangsung di tengah-tengah masyarakat harus diungkapkan.

\section{GURU INDONESIA DAN TANTANGAN PROFESIONALISME}

Pembelajaran dikatakan berhasil apabila tujuannya dapat dicapai oleh siswa. Apabila kegiatan pembelajaran yang dilaksanakan guru tidak berhasil mencapai tujuannya, sebaiknya guru melakukan refleksi dan pembenahan. Guru harus bisa merenungkan kembali terhadap persiapan, pengelolaan, dan pelaksanaannya sudah tepat atau belum tepat. Guru dapat meminta data dari teman sejawat dan atau siswa terhadap tindakan yang telah dilakukan.

Seiring dengan kemajuan teknologi, maka perkembangan media pembelajaran begitu cepat, di mana masing-masing media yang ada punya ciri-ciri dan kemampuan sendiri. Dari hal ini, kemudian timbul usaha-usaha penataannya yaitu pengelompokkan atau klasifikasi menurut kesamaan ciri-ciri atau karakteristiknya. Ciri-ciri umum dari media pembelajaran menurut (Oemar Hamalik, 1994), adalah: Pertama, Media pembelajaran identik dengan pengertian peragaan yang berasal dari kata "raga", artinya suatu benda yang dapat diraba, dilihat dan didengar dan yang dapat diamati melalui panca indera. Kedua, Tekanan utama terletak pada benda atau hal-hal yang dapat dilihat dan didengar. Ketiga, Media pembelajaran digunakan dalam rangka hubungan (komunikasi) dalam pengajaran antara guru dan siswa. Keempat, Media pembelajaran adalah semacam alat bantu belajar mengajar, baik di dalam maupun di luar kelas. Kelima, Media pembelajaran merupakan 
suatu "perantara" (medium, media) dan digunakan dalam rangka belajar.Keenam, Media pembelajaran mengandung aspek, sebagai alat dan sebagi teknik yang erat pertaliannya dengan metode belajar. 


\section{SIMPULAN}

Media pembelajaran tidak dapat dipisahkan dari proses pembelajaran, karena media pembelajaran merupakan perantara antara pengajar dengan peserta didik dalam mentransfer ilmu pengetahuan. Semakin maju perkembangan teknologi, pengajar dituntut untuk dapat berinovasi dalam mengimplementasikan media pembelajaran yang dapat menyesuaikan dengan perkembangan zaman. Ada beberapa media pembelajaran yang dapat digunakan yaitu antara lain media audio, media visual, dan media audio visual.Penggunaa media pembelajaran diharapkan dapat meningkatkan Self Motivated Learning dan Self Regulated Learning. Self Motivated Learning adalah kegiatan belajar aktif, yang didorong oleh niat atau motif untuk menguasai suatu kompetensi guna mengatasi suatu masalah, dan dibangun dengan bekal pengetahuan atau kompetensi yang telah dimiliki (Haris Mudjiman, 2009). Sedangkan Self Regulated Learning adalah cara belajar siswa aktif secara individu untuk mencapai tujuan akademik dengan cara pengontrolan perilaku, memotivasi diri sendiri dan menggunakan kognitifnya dalam belajar

\section{REFERENSI}

Anis, M. Z. A., Putro, H. P. N., Susanto, H., \& Hastuti, K. P. (2020). Historical Thinking Model in Achieving Cognitive Dimension of Indonesian History Learning. PalArch's Journal of Archaeology of Egypt/Egyptology, 17(7), 7894-7906.

Anis, M. Z. A., Susanto, H., \& Mardiani, F. (2021, February). Analysis of the Effectiveness of MPBH: The Mains of Mandai as a Saving Food in Banjarmasin Community. In The 2nd International Conference on Social Sciences Education (ICSSE 2020) (pp. 89-94). Atlantis Press.

Efendi, I., Prawitasari, M., \& Susanto, H. (2021). Implementasi Penilaian Pembelajaran Pada Kurikulum 2013 Mata Pelajaran Sejarah. Prabayaksa: Journal of History Education, 1(1), 21-25.

Susanto, H. (2020). Profesi Keguruan. Banjarmasin: FKIP Universitas Lambung Mangkurat. 
Susanto, H., \& Akmal, H. (2018). Efektivitas Penggunaan Aplikasi Pembelajaran Berbasis Mobile Smartphone Sebagai Media Pengenalan Sejarah Lokal Masa Revolusi Fisik Di Kalimantan Selatan Pada Siswa Sekolah Menengah Atas. HISTORIA: Jurnal Program Studi Pendidikan Sejarah, 6(2), 197-206.

Susanto, H., Irmawati, I., Akmal, H., \& Abbas, E. W. (2021). Media Film Dokumenter Masuknya Islam Ke Nusantara dan Pengaruhnya Terhadap Keterampilan Berpikir Kritis Siswa. HISTORIA: Jurnal Program Studi Pendidikan Sejarah, 9(1). 